\title{
PERCEPTIONS OF STUDENTS WITH VISUAL IMPAIRMENT ON INCLUSIVE EDUCATION: A NARRATIVE META-ANALYSIS
}

Original scientific paper

\author{
Hisae Miyauchi ${ }^{1}$ \\ Peter V. Paul ${ }^{2}$
}

${ }^{1}$ Faculty of Human Sciences, Division of Disability Sciences, University of Tsukuba, Japan

${ }^{2}$ Department of Educational Studies, The Ohio State University, USA

Received: 5/29/2020

Accepted: $7 / 30 / 2020$

\begin{abstract}
This study focused on the perceptions of students with visual impairment. A narrative meta-analysis was utilized to synthesize the findings of investigations that employed quantitative, qualitative, or mixed methodological designs. Based on the contents of the reviewed articles, three broad categories were established: barriers, feelings of acceptance, and successful components of inclusion. Barriers included the physical environments of schools, accessibility, and social interactions. With respect to feelings of acceptance, the constructs of homophily and fitting in were discussed. Several components of successful inclusion were delineated such as a positive school climate and a positive, supportive attitude associated with teachers, especially those who possess knowledge and skills and held high expectations for students. Students with visual impairment also needed skills to be autonomous and assertive, which are conducive to academic success and the initiation and building of friendships with sighted peers. A number of findings of the present study corroborated those from previous investigations; however, the uniqueness of this seminal research pertains to the specific perceptions of students with visual impairment in inclusive settings. Limitations of the study were also discussed.
\end{abstract} Keywords: inclusion, students with visual impairment, perceptions

\footnotetext{
${ }^{1}$ Correspondence to:

Hisae Miyauchi, PhD, Faculty of Human Sciences, Division of Disability Sciences, University of Tsukuba, Japan 1-1-1 Tennodai, Tsukuba, Ibaraki, 305-8572, JAPAN

Phone: +81 (29) 853-6803

Fax: +81 (29) 853-6803

E-mail: hmiyauch@human.tsukuba.ac.jp

Peter V. Paul, PhD, Department of Educational Studies, The Ohio State University, USA

122 Ramseyer Hall 29 W. Woodruff Ave. Columbus, OH 43210

E-mail: paul.3@osu.edu
} 
The number of children, who are blind and visually impaired and are educated in general education classrooms, has been increasing around the world. For example, in the United States, whereas in the 1960s and 70s, the majority of students with visual impairment were educated in residential schools, as of 2017 , more than $80 \%$ of these students are receiving education in general education classrooms (U.S. Department of Education, National Center for Education Statistics, 2017). The United Kingdom also has a situation similar to the United States, with more than $60 \%$ of children with visual impairment in general education classrooms (Morris \& Smith, 2007). Australia, Sweden, and Israel have an even higher percentage, proclaiming that most children with visual impairment (without any additional disabilities) are placed in general education classrooms (De Verdier \& Ek, 2014; Jessup et al., 2017; Opie, Deppler, \& Southcott, 2017).

Because inclusive education is not only an educational but also a political endeavor, the number of students with visual impairment in general education classrooms will likely continue growing in countries, including in developing countries. This increase will be fueled by several factors such as parental and student expectations and the emergence of advanced technology. In the United States and the United Kingdom, strong advocates have argued that inclusion is a civil rights issue, maintaining that separate education facilities are unequal (i.e., with respect to resources, curricula, and quality of instruction). In addition, these advocates have asserted that instruction in separate special education settings has not substantially raised the academic or social achievement level of most children with disabilities (e.g., see discussions in Byrnes, 2017; Thomas \& Vaughan, 2004; Valle \& Conner, 2011; Winzer, 2009).

With respect to the inclusion of children with disabilities, especially children with visual impairment, there are lingering concerns such as providing access to the general education curriculum and whether general education classroom teachers are able to address the needs of these children. It has been remarked that sighted individuals receive about $80 \%$ of their daily information through vision; thus, the everyday circumstances and tasks that are taken for granted by fully sighted people provide significant challenges for individuals with visual impairment (Kalloniatis \& Johnston, 1994). This is also the case for children with visual impairment in general education classrooms; these children are affected both academically and socially by classroom situations (Brydges \& Mkandawire, 2017; Jessup et al., 2017; Opie et al., 2017; West et al., 2004). For example, due to the nature of the disability, recognizing familiar faces is one of the difficult tasks, making it challenging for children with visual impairment to find and approach friends, especially during recess times (Kalloniatis \& Johnston, 1994).

In considering possible barriers to the effective inclusion of children with visual impairment, there are challenges related to general education instruction, the use of resources in the classroom environment, and the structure and pace of activities that can impede academic and social success. For example, children with visual impairment may experience difficulties with accessing information on the blackboard or SmartBoard, regardless of the use of assistive technologies (Kalloniatis \& Johnston, 1994; Opie, 2018). Lack of support by general education classroom teachers, assistants, and professionals, who do not possess adequate knowledge about visual impairment, is another common issue (Brydges \& Mkandawire, 2017; Jessup et al., 2017; Opie et al., 2017; Whitburn, 2014). Consider an example involving participation in physical education programs. Due to a lack of teachers' knowledge of visual impairment and adapted sports, many children with visual impairment in mainstream or inclusive education classrooms are excluded from participating in activities. These children may simply be situated on the sidelines or engaged in different physical activities with teacher assistants (Haegele \& Porretta, 2015; Haegele \& Zhu, 2017). The above examples provide evidence that the physical proximity of children with visual impairment with sighted children in classrooms and schools does not constitute a successful inclusive education endeavor. 
With the rise of disability studies and the awareness of a social model of disability, there has been an increase in research that focus on personal stories and voices of individuals with disabilities and their stakeholders (e.g., Bishop, 1986; Chang \& Schaller, 2002; Hess, 2010; Whitburn, 2014). This research thrust on perceptions, involving students, parents or caregivers, and professionals, can provide a better understanding of the barriers and recommendations to improve the inclusive environment. In general, perceptions refer to the "generalizations about things such as causality or the meaning of specific actions" (Yero, 2002, p. 21, with respect to teachers). This can influence decisions, attitudes, and even behaviors exhibited by individuals. If perceptions are not explicit, it is possible to uncover the implications by observing the actions of individuals - that is, their utterances or behaviors. Perceptions are often influenced by background, education, and experiences.

With respect to the perceptions of students with visual impairment, Jessup et al. (2017) found that, although there were positive experiences related by the high school age students, one-third of them were not satisfied with their social relationships. Qualitative research by Whitburn (2014), De Verdier and Ek (2014), and Opie et al. (2017) reported that children with visual impairment are under constant pressure to make adjustments and to prove their capabilities to teachers and peers by trying to excel academically or socially. For those who could not excel, these children either externalized their anger and frustration to their teachers or simply lost interest in school. They became distance from their peers or skipped a number of classes (Chang \& Schaller, 2002).

Although there is research pertaining to the inclusion of children with visual impairment, including their perceptions of inclusion, there is no research that has analyzed and synthesized the available findings. A meta-analysis or meta-synthesis is critical for understanding the trends and for advancing our knowledge regarding the inclusion of children with visual impairment. In general, a meta-analysis is an in-depth evaluation of a range of research studies that use various methodologies such as quantitative, qualitative, or mixed (e.g., Gall, Gall, \& Borg, 2007, 2015; Galvan, 2012). There is a methodology for including, excluding, and analyzing the findings of studies. Although details such as demographics, instruments, and a few quality indicators are documented in the present study, we do not evaluate the merits of the quality indicators (e.g., see discussions in Booth, Sutton, \& Papioannou, 2016; Collins \& Fauser, 2005; Council for Exceptional Children, 2014). If we had engaged in the evaluation of quality indicators, we would have had fewer investigations for our analysis.

After providing an overview of research pertaining to inclusion and students with visual impairment, the major aim of this paper is to synthesize the findings of the perceptions of these students on inclusive education. This synthesis is also influenced by our professional experiences and education. The following research questions are addressed:

What are the general perceptions of students with visual impairment regarding:

- Barriers in inclusive education?

- Their feelings of acceptance in an inclusive environment?

- Successful components of inclusive education?

We expect to uncover a range of issues such as the support, attitudes, and qualifications of administrators, teachers, and other professionals; the availability of accessible technology; the use of Braille and orientation and mobility; and collaborations between general education teachers and teachers of students with visual impairment.

\section{METHOD}

With respect to obtaining a general overview of research, we conducted a systematic database search on inclusion and visual impairment, using the following major electronic search engines pertaining 
to special education: Education Full Text (Wilson), ERIC, EBSCOhost, ProQuest, and PsycInfo. The specific descriptor words and phrases were: visually impaired (or visual impairment or low vision or blind), inclusive education (or inclusion or mainstreaming or integration), academic achievement (or academic performance or academic success) and social skills (or social interaction or social behavior or social competence). After duplicates were eliminated, a total of 472 articles were identified.

We perused independently the titles and abstracts for all 472 journal articles, using the following inclusion criteria:

- The article must be related to children with visual impairment, learning in mainstream or inclusive settings.

- The participants in the article must have a visual impairment (blind or low vision), and the results are mainly derived from their perceptions.

- The students must be in a compulsory education program (that is, $1^{\text {st }}$ to $12^{\text {th }}$ grade).

We excluded articles that only focused on children with visual impairment with additional disabilities. Children with multiple disabilities exhibit more challenges and need additional resources for effective inclusion compared to children with only visual impairment (De Verdier \& Ek, 2014; Jessup et al., 2018). Given this situation, these children should be examined separately to minimize confounding findings and to better understand the inclusion of various cohorts of individuals with visual impairment. We did not exclude articles that included children with an additional disability, teachers, and parents as long as children with visual impairment was their main focus.

After applying the inclusion criteria and our initial evaluations, 94 potential relevant articles were identified. We evaluated independently the full texts of these 94 studies. Articles that did not meet the previously mentioned inclusion criteria were eliminated, resulting in a total of 64 remaining articles. After reading and evaluating the full texts of these articles and reaching a consensus, we organized the content into several broad categories: research method, area/main research theme, country where the study took place, and year of publication.

The 64 articles were reread and further categorized, using a thematic qualitative analysis. A thematic analysis is an approach that involves identifying, analyzing, and reporting patterns or themes within data (Braun \& Clarke, 2006). We independently reviewed the full texts and reached a consensus on a list of themes. As a result, a total of five broad research themes emerged: "Perspective (attitude, feeling, opinion)", "Mental Health", "Self-esteem and Social Support", "Content of Topic" (literacy, mathematics, etc.), and "Other" (miscellaneous, due to the range of diverse topics). Of the 64 articles, 23 were categorized under "perspective", two articles under "mental health", one under "self-esteem and social support", 37 under "content of topic", and one under "other". Due to the broad themes and the ample number of articles, we decided to focus on the "Perspective" area, involving mainly the perceptions of students with visual impairment. This focus resulted in the identification of 14 relevant articles for review.

In addition to the above-mentioned process, a separate manual search of eight journals was undertaken electronically. The eight journals were: International Journal of Disability, Journal of Visual Impairment \& Blindness, The British Journal of Visual Impairment, European Journal of Special Needs Education, Rehabilitation Education for Blindness and Visual Impairment, Support for Learning, Journal of Research in Special Educational Needs, and Australasian Journal of Special Education. The selected 14 relevant articles were published in these journals. As a result, we identified 40 additional articles via this manual search, excluding duplicates. The titles and abstracts of these articles were screened independently. Adhering to the same inclusion criteria and focusing on the perceptions of students with visual impairment, four new articles were added to the original 14 relevant articles. 
A total of 18 articles were evaluated described methodology. The 16 articles that met the independently and were reassessed for eligibility. full inclusion criteria were analyzed with respect to We developed a narrative summary of each article providing information pertaining to one or more of and compared our discussions of the contents. the three research questions listed previously. Figure Two of the 18 articles were eliminated due to 1 illustrates the process leading to the final list of 16 inconsistency in the stated results and/or inadequate studies for our analysis.

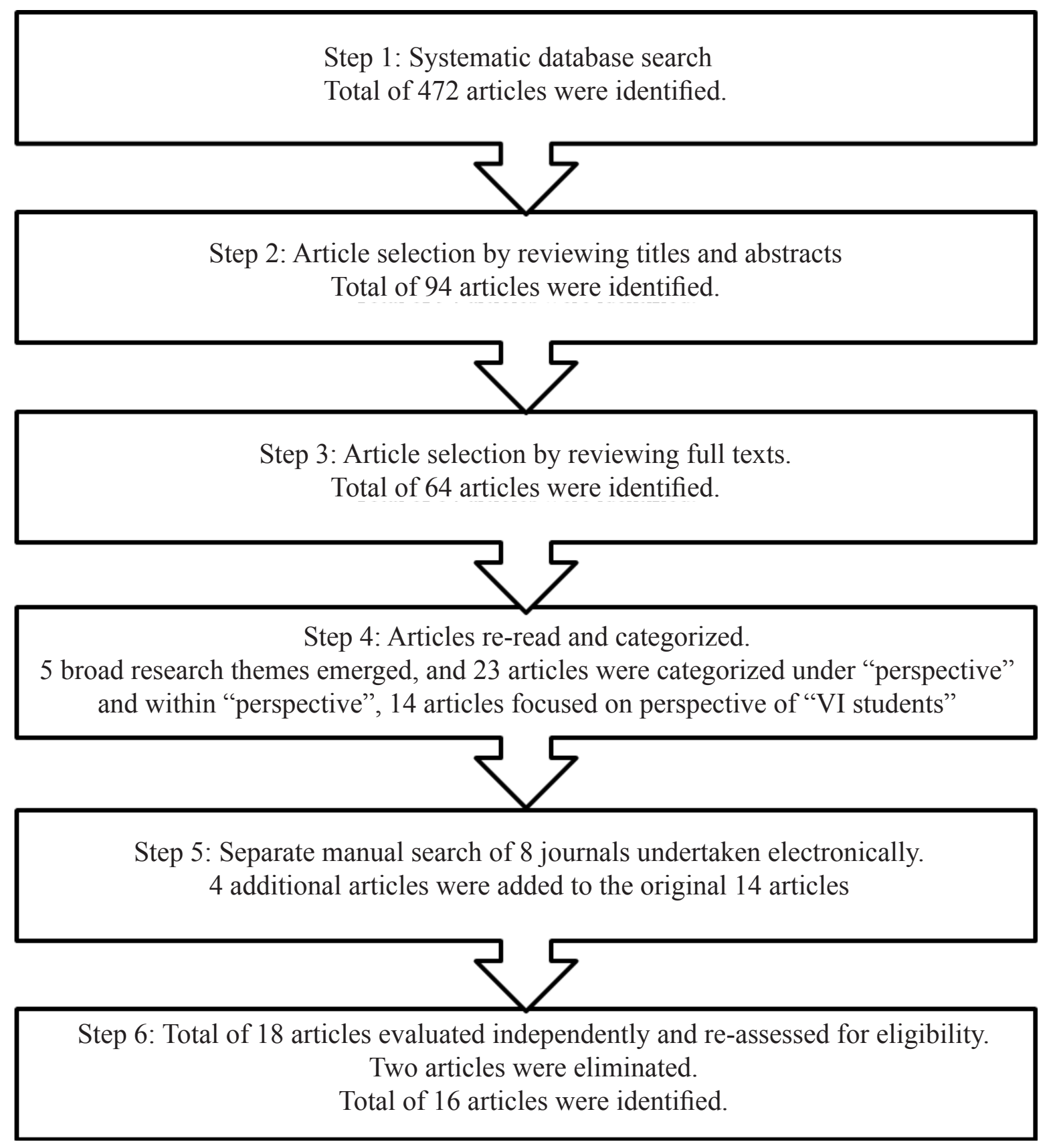

Figure 1. Process for the Selection of Articles

Of the 16 articles, seven articles (Brydges (such as teachers and parents) to supplement children \& Mkandawire, 2017; Lieberman, Robinson, \& with visual impairment's perceptions. The remaining Rollheiser, 2006; Opie \& Southcott, 2015; Opie, 2018; six articles (Bishop, 1986; Chang \& Schaller, Thurston, 2014; West et al., 2004; Whitburn, 2014) 2002; Hess, 2010; Jessup et al., 2017; Jessup et al. focused solely on children with visual impairment, 2018; Koutsouris, 2014) focused on children with and three others (De Verdier \& Ek, 2014; George visual impairment, but included some children with \& Duquette, 2006; Opie et al., 2017) focused on additional disabilities, teachers, and parents. children with visual impairment, but included others 
As mentioned above, the systematic search of databases and journals yielded 16 articles that met our inclusion criteria and the main focus on perceptions of students with visual impairment. Table 1 presents the summaries of the research articles. The results of the meta-analysis are reported for each research question below.

Table 1. Summary of the 16 Reviewed Articles

\begin{tabular}{|c|c|c|c|c|c|}
\hline Author \& Date & Country & Research Purpose & Methods & Participants & Findings \\
\hline $\begin{array}{l}\text { Bishop (1986) } \\
\text { 【Successful } \\
\text { components } \\
\text { of inclusive } \\
\text { education】 }\end{array}$ & USA & $\begin{array}{l}\text { To identify the } \\
\text { components } \\
\text { of success in } \\
\text { mainstreaming } \\
\text { for students with } \\
\text { visual impairment } \\
\text { as perceived by } \\
\text { teachers of the } \\
\text { visually impaired, } \\
\text { general education } \\
\text { teachers, school } \\
\text { principals, } \\
\text { parents, and } \\
\text { students } \\
\text { with visual } \\
\text { impairment. }\end{array}$ & $\begin{array}{l}\text { Three-part } \\
\text { questionnaire, } \\
\text { which consisted } \\
\text { of open-ended } \\
\text { questions; rank } \\
\text { ordering of } \\
\text { factors selected } \\
\text { from a review } \\
\text { of literature; } \\
\text { and value } \\
\text { judgments were } \\
\text { used. Analyzed } \\
\text { quantitatively. }\end{array}$ & $\begin{array}{l}304 \text { participants, } \\
\text { consisting of } \\
\text { teachers of } \\
\text { students with VI } \\
\text { (88), classroom } \\
\text { teachers (62), } \\
\text { school principals } \\
\text { (52), parents of } \\
\text { students with VI } \\
\text { (56), current and } \\
\text { former students } \\
\text { with VI (46). }\end{array}$ & $\begin{array}{l}70 \text { factors were } \\
\text { perceived as } \\
\text { associated } \\
\text { with success in } \\
\text { mainstreaming } \\
\text { for VI students. } \\
\text { Of these, } 19 \text { were } \\
\text { pupil variables, } 9 \\
\text { were school-related, } \\
5 \text { concerned the } \\
\text { family, and one } \\
\text { was a community } \\
\text { factor. Among the } \\
10 \text { most important } \\
\text { variables, half were } \\
\text { pupil related, } 4 \text { were } \\
\text { school factors, and } \\
\text { one concerned the } \\
\text { family. }\end{array}$ \\
\hline $\begin{array}{l}\text { Brydges \& } \\
\text { Mkandawire } \\
\text { (2017) } \\
\text { 【Barriers } \\
\text { in inclusive } \\
\text { education】 } \\
\text { 【Feelings of } \\
\text { acceptance in } \\
\text { an inclusive } \\
\text { environment】 }\end{array}$ & Africa & $\begin{array}{l}\text { To investigate } \\
\text { the experiences } \\
\text { of students with } \\
\text { VI in Lagos, } \\
\text { Nigeria. Explored } \\
\text { the perceptions } \\
\text { of the education } \\
\text { policies on VI in } \\
\text { Lagos; examined } \\
\text { the degree of } \\
\text { government } \\
\text { and community } \\
\text { support for } \\
\text { inclusive } \\
\text { education; and } \\
\text { investigated } \\
\text { salient } \\
\text { sociocultural } \\
\text { conditions that } \\
\text { set the context } \\
\text { for inclusive } \\
\text { education }\end{array}$ & $\begin{array}{l}\text { Qualitative } \\
\text { method. } \\
\text { In-depth, semi- } \\
\text { structured } \\
\text { interviews situated } \\
\text { within critical } \\
\text { disability theory } \\
\text { were conducted. } \\
\text { The analysis } \\
\text { looked for } \\
\text { recurring responses } \\
\text { and developed } \\
\text { categories. Within } \\
\text { the categories, } \\
\text { further themes that } \\
\text { illustrated the key } \\
\text { experiences of the } \\
\text { respondents were } \\
\text { identified. }\end{array}$ & $\begin{array}{l}\text { Participants } \\
\text { were } 17 \text { students } \\
\text { with VI. All } \\
\text { attending junior } \\
\text { secondary (12- } \\
15 \text { years of age) } \\
\text { public inclusive } \\
\text { schools. Most } \\
\text { had previously } \\
\text { attended a } \\
\text { special school. }\end{array}$ & $\begin{array}{l}\text { Three major themes } \\
\text { emerged: Lack } \\
\text { of supplementary } \\
\text { instruction; lack } \\
\text { of specialized } \\
\text { instruction and } \\
\text { classroom support; } \\
\text { and bullying. } \\
\text { Overall, inclusive } \\
\text { education was } \\
\text { seen as potentially } \\
\text { beneficial by the } \\
\text { students. Students } \\
\text { were gaining new } \\
\text { social skills and } \\
\text { understanding of the } \\
\text { broader world. }\end{array}$ \\
\hline
\end{tabular}




\begin{tabular}{|c|c|c|c|c|c|}
\hline Author \& Date & Country & Research Purpose & Methods & Participants & Findings \\
\hline $\begin{array}{l}\text { Chang \& } \\
\text { Schaller (2002) } \\
\text { 【Successful } \\
\text { components } \\
\text { of inclusive } \\
\text { education】 }\end{array}$ & USA & $\begin{array}{l}\text { To examine the } \\
\text { perceptions of } \\
\text { students with } \\
\text { VI on teacher's } \\
\text { support for } \\
\text { their needs in } \\
\text { the educational } \\
\text { settings }\end{array}$ & $\begin{array}{l}\text { Qualitative } \\
\text { research design, } \\
\text { using semi- } \\
\text { structured in-depth } \\
\text { interviews and data } \\
\text { analysis. Data } \\
\text { analysis was based } \\
\text { on three levels of } \\
\text { coding and cross- } \\
\text { case analysis. }\end{array}$ & $\begin{array}{l}\text { Participants } \\
\text { were } 12 \\
\text { adolescents } \\
\text { with visual } \\
\text { impairment. Of } \\
\text { the } 12 \text {, one had } \\
\text { an additional } \\
\text { disability } \\
\text { (hearing } \\
\text { impairment). } \\
8 \text { attended } \\
\text { mainstream } \\
\text { schools; } 4 \\
\text { students } \\
\text { attended special } \\
\text { schools. }\end{array}$ & $\begin{array}{l}\text { The emotional and } \\
\text { learning needs of VI } \\
\text { children emerged } \\
\text { from the analysis. } \\
\text { Teachers listened } \\
\text { and encouraged VI } \\
\text { students to excel } \\
\text { like the sighted } \\
\text { students and believe } \\
\text { that they were } \\
\text { capable. } \\
\text { A variety of } \\
\text { instructional } \\
\text { strategies, including } \\
\text { tactile cues, } \\
\text { active learning, } \\
\text { cooperative } \\
\text { learning groups, the } \\
\text { provision of braille } \\
\text { materials, and } \\
\text { assistive technology } \\
\text { were identified. } \\
\text { Some VI students } \\
\text { expressed a lack } \\
\text { of support for both } \\
\text { needs (emotional } \\
\text { and learning). }\end{array}$ \\
\hline $\begin{array}{l}\text { De Verdier \& } \\
\text { Ek (2014) } \\
\text { 【Barriers } \\
\text { in inclusive } \\
\text { education】 }\end{array}$ & Sweden & $\begin{array}{l}\text { To examine } \\
\text { reading } \\
\text { development, } \\
\text { academic } \\
\text { achievement of } \\
\text { students with } \\
\text { VI learning in } \\
\text { inclusive settings, } \\
\text { and the support } \\
\text { received. }\end{array}$ & $\begin{array}{l}\text { Qualitative } \\
\text { method was } \\
\text { used. Interview } \\
\text { (semi-structured } \\
\text { for all students, } \\
\text { one parent, and } \\
\text { one teacher per } \\
\text { student), and } \\
\text { documents such } \\
\text { as observation } \\
\text { reports and grades } \\
\text { for each subject } \\
\text { were collected and } \\
\text { analyzed. }\end{array}$ & $\begin{array}{l}\text { Participants } \\
\text { included } 6 \\
\text { students with } \\
\text { blindness or } \\
\text { severe visual } \\
\text { impairment } \\
\text { in inclusive } \\
\text { educational } \\
\text { settings; one of } \\
\text { their parents and } \\
\text { teachers. }\end{array}$ & $\begin{array}{l}\text { The outcome varied } \\
\text { in all three aspects. } \\
\text { Two students had } \\
\text { satisfactory support } \\
\text { from the school; } \\
\text { however, most } \\
\text { had dissatisfactory } \\
\text { level of support. } \\
\text { Overall, no } \\
\text { difference in reading } \\
\text { comprehension } \\
\text { compared to sighted } \\
\text { readers was found. } \\
\text { Differences were } \\
\text { seen in decoding } \\
\text { and reading speed. } \\
\text { All students that } \\
\text { attended general } \\
\text { education classes } \\
\text { had average grades. }\end{array}$ \\
\hline
\end{tabular}




\begin{tabular}{|c|c|c|c|c|c|}
\hline Author \& Date & Country & Research Purpose & Methods & Participants & Findings \\
\hline $\begin{array}{l}\text { George \& } \\
\text { Duquette } \\
\text { (2006) } \\
\text { 【Barriers } \\
\text { in inclusive } \\
\text { education】 } \\
\\
\text { 【Successful } \\
\text { components } \\
\text { of inclusive } \\
\text { education】 }\end{array}$ & Canada & $\begin{array}{l}\text { To understand } \\
\text { the social and } \\
\text { psychological } \\
\text { experiences of } \\
\text { a student with } \\
\text { low vision, and } \\
\text { suggest a model } \\
\text { for successful } \\
\text { inclusion. }\end{array}$ & $\begin{array}{l}\text { Qualitative } \\
\text { method. A single } \\
\text { case study with } \\
\text { a constructivist } \\
\text { approach was } \\
\text { conducted. Sources } \\
\text { of data including } \\
\text { semi-structured } \\
\text { interviews, } \\
\text { observations } \\
\text { (field notes), } \\
\text { and documents } \\
\text { (school files) were } \\
\text { collected over } \\
2 \text { months. Data } \\
\text { were analyzed } \\
\text { inductively and } \\
\text { were divided } \\
\text { into meaningful } \\
\text { units; coded and } \\
\text { organized into } \\
\text { categories. }\end{array}$ & $\begin{array}{l}\text { Participant } \\
\text { was a 11-year- } \\
\text { old male with } \\
\text { low-vision } \\
\text { (oculocutaneous } \\
\text { albinism and } \\
\text { nystagmus } \\
\text {-20/100 with } \\
\text { correction). } \\
\text { Participants } \\
\text { include student's } \\
\text { current and } \\
\text { previous } \\
\text { year's teachers } \\
\text { (veteran teachers } \\
\text { with teaching } \\
\text { experience } \\
\text { of } 18+\text { years) } \\
\text { who previously } \\
\text { taught the } \\
\text { VI student; } \\
\text { mother was also } \\
\text { involved. }\end{array}$ & $\begin{array}{l}\text { Four themes were } \\
\text { derived: sports; } \\
\text { friendships and } \\
\text { popularity; role of } \\
\text { the teacher; role } \\
\text { of the parent. Role } \\
\text { of sports was the } \\
\text { central theme. } \\
\text { Teachers had a } \\
\text { positive image of } \\
\text { the student with } \\
\text { VI and had high } \\
\text { expectations for all } \\
\text { students. Physical } \\
\text { education was } \\
\text { the most difficult } \\
\text { subject to include } \\
\text { the student with } \\
\text { VI. The student has } \\
\text { two caring parents, } \\
\text { and the mother } \\
\text { worked closely } \\
\text { with teachers. It } \\
\text { was concluded } \\
\text { that psychosocial } \\
\text { development of } \\
\text { students with } \\
\text { low vision may } \\
\text { not always be } \\
\text { compromised by } \\
\text { limitations. The } \\
\text { four elements } \\
\text { that supported } \\
\text { the student's } \\
\text { successful inclusion } \\
\text { were "parental } \\
\text { and familial } \\
\text { system", "teacher- } \\
\text { instructional } \\
\text { system", "personal } \\
\text { system" and "peer } \\
\text { system" }\end{array}$ \\
\hline $\begin{array}{l}\text { Hess (2010) } \\
\text { 【Successful } \\
\text { components } \\
\text { of inclusive } \\
\text { education】 }\end{array}$ & & $\begin{array}{l}\text { To investigate the } \\
\text { interrelationships } \\
\text { of the school } \\
\text { climate, teachers' } \\
\text { attitudes, and the } \\
\text { quality of life } \\
\text { (QOL) of students } \\
\text { with visual } \\
\text { impairment. }\end{array}$ & $\begin{array}{l}\text { A quantitative } \\
\text { method was used. } \\
\text { Measurements } \\
\text { used: } \\
\text { Questionnaire on } \\
\text { school climate } \\
\text { and staff attitudes; } \\
\text { Questionnaire } \\
\text { on feelings of } \\
\text { depression. }\end{array}$ & $\begin{array}{l}\text { Participants } \\
\text { were } 63 \text { VI } \\
\text { students, ages } \\
12 \text { to } 19 \text { years, } \\
\text { attending } \\
\text { mainstream } \\
\text { schools; from } \\
40 \text { different } \\
\text { schools all over } \\
\text { Israel. Total of } \\
200 \text { teachers } \\
\text { involved. }\end{array}$ & $\begin{array}{l}\text { When the school } \\
\text { climate and } \\
\text { teacher's attitudes } \\
\text { towards inclusion } \\
\text { were positive, there } \\
\text { was a significant } \\
\text { correlation of the } \\
\text { teachers' assessment } \\
\text { of the students } \\
\text { (social, emotional, } \\
\text { and learning } \\
\text { domains) and the } \\
\text { students' evaluation } \\
\text { of their QOL. When } \\
\text { climate and attitudes } \\
\text { were positive, the } \\
\text { students perceived } \\
\text { that stigma was } \\
\text { lower. }\end{array}$ \\
\hline
\end{tabular}




\begin{tabular}{|c|c|c|c|c|c|}
\hline Author \& Date & Country & Research Purpose & Methods & Participants & Findings \\
\hline $\begin{array}{l}\text { Jessup et. al } \\
\text { (2017) } \\
\text { 【Barriers } \\
\text { in inclusive } \\
\text { education】 } \\
\\
\text { 【Feelings of } \\
\text { acceptance in } \\
\text { an inclusive } \\
\text { environment】 }\end{array}$ & Australia & $\begin{array}{l}\text { To explore the } \\
\text { social experiences } \\
\text { of VI students } \\
\text { in high school } \\
\text { by addressing } \\
\text { following } \\
\text { questions. } \\
\text { a. How socially } \\
\text { included do VI } \\
\text { students feel at } \\
\text { high school? } \\
\text { b. What are the } \\
\text { internal qualities } \\
\text { (awareness, fitting } \\
\text { in, acceptance, } \\
\text { loneliness, } \\
\text { enjoyment) } \\
\text { of their school } \\
\text { activities and } \\
\text { interactions? } \\
\text { c. What are } \\
\text { the different } \\
\text { influences on } \\
\text { social inclusion in } \\
\text { high school? }\end{array}$ & $\begin{array}{l}\text { Mixed method } \\
\text { was used. } \\
\text { Measurements } \\
\text { included: } \\
\text { Experience } \\
\text { Sampling } \\
\text { Methodology } \\
\text { (ESM), } \\
\text { Psychological } \\
\text { Sense of School } \\
\text { Membership } \\
\text { (PSSM) } \\
\text { questionnaire, } \\
\text { and interview. } \\
\text { Interviews } \\
\text { corroborated the } \\
\text { ESM responses } \\
\text { and explored social } \\
\text { aspects further. }\end{array}$ & $\begin{array}{l}\text { Participants } \\
\text { were 12 VI } \\
\text { students, 13-17 } \\
\text { years old from } \\
12 \text { different } \\
\text { high schools. } \\
\text { Three out of } 12 \\
\text { were VI with } \\
\text { an additional } \\
\text { disability. All } \\
\text { had varying } \\
\text { degrees of } \\
\text { vision loss } \\
\text { ranging from } \\
\text { total blindness } \\
\text { (4 participants) } \\
\text { to low vision } \\
\text { (but all were } \\
\text { severe). }\end{array}$ & $\begin{array}{l}\text { All except for some } \\
\text { with additional } \\
\text { disabilities felt } \\
\text { included and had } \\
\text { a positive sense of } \\
\text { belonging. Over half } \\
\text { the time, students } \\
\text { felt school was } \\
\text { enjoyable; yet, } \\
\text { almost 1/3 of the } \\
\text { time they felt a } \\
\text { little or quite lonely. } \\
\text { "Doing nothing" } \\
\text { was experienced } \\
\text { negatively by } \\
\text { students, and it } \\
\text { was often seen } \\
\text { in mathematics, } \\
\text { physical education, } \\
\text { and lunchtime. They } \\
\text { felt most accepted } \\
\text { doing activities } \\
\text { with a group of } \\
\text { friends (not with } \\
\text { staff or a single } \\
\text { friend). In class, } \\
\text { unreciprocated } \\
\text { help was received } \\
\text { by } 44 \% \text { of them; } \\
\text { the majority came } \\
\text { from staff. Student } \\
\text { reciprocation-- } \\
\text { by helping other } \\
\text { students--was } \\
\text { low ( } 8 \% \text { ). No } \\
\text { correlations } \\
\text { found for gender, } \\
\text { age, grade, level } \\
\text { of vision and } \\
\text { ICSEA (index } \\
\text { of community } \\
\text { socio-educational } \\
\text { advantage). } \\
\text { Factors that } \\
\text { influenced students' } \\
\text { perceptions were } \\
\text { the presence of } \\
\text { additional disability, } \\
\text { fitting in, and } \\
\text { loneliness. }\end{array}$ \\
\hline
\end{tabular}




\begin{tabular}{|c|c|c|c|c|c|}
\hline Author \& Date & Country & Research Purpose & Methods & Participants & Findings \\
\hline $\begin{array}{l}\text { Jessup et. al } \\
\text { (2018) } \\
\text { [Barriers in } \\
\text { inclusive } \\
\text { education】 } \\
\\
\text { 【Feelings of } \\
\text { acceptance in } \\
\text { an inclusive } \\
\text { environment】 } \\
\text { 【Successful } \\
\text { components } \\
\text { of inclusive } \\
\text { education】 }\end{array}$ & Australia & $\begin{array}{l}\text { To explore } \\
\text { social inclusion } \\
\text { in high school } \\
\text { of Australian } \\
\text { students with } \\
\text { visual impairment } \\
\text { by understanding } \\
\text { how students } \\
\text { described social } \\
\text { inclusion, } \\
\text { whether they felt } \\
\text { included, and } \\
\text { what influenced } \\
\text { these perceptions. }\end{array}$ & $\begin{array}{l}\text { Part of a } \\
\text { larger mixed } \\
\text { methods study. } \\
\text { Psychological } \\
\text { Sense of School } \\
\text { Membership } \\
\text { (PSSM) was } \\
\text { used to measure } \\
\text { the subjective } \\
\text { sense of school } \\
\text { belonging, and } \\
\text { semi-structured } \\
\text { interview was } \\
\text { conducted on } \\
\text { thoughts and the } \\
\text { actual experiences } \\
\text { of social inclusion. }\end{array}$ & $\begin{array}{l}\text { Participants } \\
\text { were } 12 \text { high } \\
\text { school students } \\
\text { with VI (13- } \\
17 \text { years); } 3 \\
\text { with additional } \\
\text { disabilities. }\end{array}$ & $\begin{array}{l}\text { Inclusion was } \\
\text { described as: being } \\
\text { noticed and not } \\
\text { overlooked or } \\
\text { ignored by others. } \\
2 / 3 \text { of the group was } \\
\text { satisfied with the } \\
\text { social relationships } \\
\text { whereas } 1 / 3 \text { was } \\
\text { not, which included } \\
\text { all students } \\
\text { with additional } \\
\text { disabilities. } \\
\text { Students' } \\
\text { perceptions and } \\
\text { experiences of } \\
\text { social inclusion } \\
\text { were encompassed } \\
\text { by five themes: } \\
\text { putting myself } \\
\text { forward; knowing } \\
\text { me; having control; } \\
\text { having a place to } \\
\text { shine; and peer } \\
\text { exclusion and } \\
\text { rejection. }\end{array}$ \\
\hline $\begin{array}{l}\text { Koutsouris } \\
\text { (2014) } \\
\text { 【Feelings of } \\
\text { acceptance in } \\
\text { an inclusive } \\
\text { environment】 }\end{array}$ & England & $\begin{array}{l}\text { To examine } \\
\text { young people } \\
\text { with and without } \\
\text { disabilities' } \\
\text { tension between } \\
\text { homophily and } \\
\text { inclusion }\end{array}$ & $\begin{array}{l}\text { Qualitative } \\
\text { research. Data } \\
\text { collection was } \\
\text { both inductive } \\
\text { (data driven) and } \\
\text { deductive (theory } \\
\text { driven); indepth } \\
\text { semi-structured } \\
\text { interviews were } \\
\text { conducted. } \\
\text { Interviews } \\
\text { focused on four } \\
\text { different scenarios } \\
\text { influenced by } \\
\text { research in moral } \\
\text { psychology. }\end{array}$ & $\begin{array}{l}27 \text { young } \\
\text { individuals } \\
\text { from special } \\
\text { and mainstream } \\
\text { schools, } \\
\text { disability } \\
\text { services, and } \\
\text { employees } \\
\text { from local } \\
\text { public houses } \\
\text { participated. } \\
\text { Of the 27, } 10 \\
\text { had invisible } \\
\text { disabilities } \\
\text { (Asperger } \\
\text { syndrome), } \\
9 \text { had visible } \\
\text { disabilities } \\
\text { (visually } \\
\text { impairment), } \\
\text { and } 8 \text { were } \\
\text { individuals } \\
\text { without } \\
\text { disabilities. Age } \\
\text { range was } 15 \text { to } \\
25 \text { years. }\end{array}$ & $\begin{array}{l}\text { Participants } \\
\text { identified a tension } \\
\text { between homophily } \\
\text { and inclusion; } \\
\text { they supported one } \\
\text { of the two sides. } \\
\text { Homophily can be } \\
\text { a choice or viewed } \\
\text { as a discrimination } \\
\text { against different } \\
\text { people and, } \\
\text { therefore, can be } \\
\text { right and wrong at } \\
\text { the same time. No } \\
\text { major differences } \\
\text { between the } \\
\text { responses of the } \\
\text { young people } \\
\text { with and without } \\
\text { disabilities. }\end{array}$ \\
\hline
\end{tabular}




\begin{tabular}{|c|c|c|c|c|c|}
\hline Author \& Date & Country & Research Purpose & Methods & Participants & Findings \\
\hline $\begin{array}{l}\text { Lieberman et. } \\
\text { al (2006) } \\
\text { 【Barriers } \\
\text { in inclusive } \\
\text { education】 } \\
\text { 【Successful } \\
\text { components } \\
\text { of inclusive } \\
\text { education】 }\end{array}$ & USA & $\begin{array}{l}\text { To examine the } \\
\text { experiences of } \\
\text { students with } \\
\text { VI in inclusive } \\
\text { general physical } \\
\text { education } \\
\text { classes in regard } \\
\text { to types of } \\
\text { modifications and } \\
\text { their awareness } \\
\text { regarding their } \\
\text { Individual } \\
\text { Education Plans. }\end{array}$ & $\begin{array}{l}\text { Qualitative method } \\
\text { was used. Three } \\
\text { parts: Questions } \\
\text { pertaining to } \\
\text { modifications to } \\
\text { equipment and } \\
\text { to rules, listing } \\
\text { of the most } \\
\text { and least liked } \\
\text { sport activities, } \\
\text { and knowledge } \\
\text { on Individual } \\
\text { Education Plans. } \\
\text { Intuitive and } \\
\text { inductive } \\
\text { processes were } \\
\text { used for analysis. }\end{array}$ & $\begin{array}{l}\text { Participants } \\
\text { were } 60 \text { children } \\
\text { and youth } \\
\text { with visual } \\
\text { impairment } \\
\text { (9-23 years } \\
\text { old) enrolled } \\
\text { in inclusive } \\
\text { general physical } \\
\text { education } \\
\text { classes and } \\
\text { attended a } \\
\text { 1-week sports } \\
\text { camp in Alaska, } \\
\text { New York, or } \\
\text { Arizona. }\end{array}$ & $\begin{array}{l}\text { Results varied } \\
\text { depending on the } \\
\text { level of the vision } \\
\text { loss. Children and } \\
\text { youth with severe } \\
\text { visual impairment } \\
\text { had experienced } \\
\text { more modifications } \\
\text { related to sounds } \\
\text { and physical and } \\
\text { verbal assistance. } \\
\text { Group of students } \\
\text { with severe VI } \\
\text { liked open sports } \\
\text { although the sports } \\
\text { were difficult to } \\
\text { modify. Severe VI } \\
\text { group was aware of } \\
\text { their IEPs, but some } \\
\text { of the students with } \\
\text { less severe VI were } \\
\text { not aware. }\end{array}$ \\
\hline $\begin{array}{l}\text { Opie (2018) } \\
\text { 【Barriers } \\
\text { in inclusive } \\
\text { education】 }\end{array}$ & Australia & $\begin{array}{l}\text { To examine the } \\
\text { perceptions of } \\
\text { students with } \\
\text { VI on their } \\
\text { experiences } \\
\text { in mainstream } \\
\text { secondary schools } \\
\text { in relation to } \\
\text { technology. }\end{array}$ & $\begin{array}{l}\text { Qualitative } \\
\text { research. } \\
\text { 2-3 indepth, } \\
\text { semi-structured } \\
\text { interviews within } \\
\text { a } 3 \text { months period } \\
\text { were conducted; } \\
\text { one interview was } \\
\text { approximately } \\
\text { one-hour in } \\
\text { duration. An } \\
\text { interpretative } \\
\text { phenomenological } \\
\text { analysis (IPA) was } \\
\text { conducted. }\end{array}$ & $\begin{array}{l}\text { Participants } \\
\text { include seven } \\
\text { students with } \\
\text { VI attending } \\
\text { secondary } \\
\text { mainstream } \\
\text { schools. } 3 \text { girls, } \\
4 \text { boys; } 1 \text { in } \\
\text { year } 10 \text { ( } 17 \text { years } \\
\text { old); the other } 6 \\
\text { students in year } \\
12 \text { ( } 18 \text { or } 19 \\
\text { years old). }\end{array}$ & $\begin{array}{l}\text { Participants found } \\
\text { access to work on } \\
\text { the board and access } \\
\text { to worksheets } \\
\text { problematic. } \\
\text { Also, teachers } \\
\text { had a limited } \\
\text { understanding of } \\
\text { VI and expertise } \\
\text { for technology } \\
\text { introduction and } \\
\text { support. VI students } \\
\text { shied away from } \\
\text { using technology } \\
\text { that singled them } \\
\text { out; students did not } \\
\text { have enough time to } \\
\text { set the technology } \\
\text { up in class, which } \\
\text { affected the use. }\end{array}$ \\
\hline
\end{tabular}




\begin{tabular}{|c|c|c|c|c|c|}
\hline Author \& Date & Country & Research Purpose & Methods & Participants & Findings \\
\hline $\begin{array}{l}\text { Opie et. al } \\
\text { (2017) } \\
\text { 【Barriers } \\
\text { in inclusive } \\
\text { education】 }\end{array}$ & Australia & $\begin{array}{l}\text { To examine } \\
\text { how effectively } \\
\text { students with VI } \\
\text { were supported } \\
\text { in the inclusive } \\
\text { setting. }\end{array}$ & $\begin{array}{l}\text { Qualitative method } \\
\text { was used. Indepth, } \\
\text { semi-structured } \\
\text { interviews were } \\
\text { conducted with } \\
7 \text { students. Brief } \\
\text { interviews to } \\
\text { augment the } \\
\text { information of } \\
\text { students were } \\
\text { conducted with } 16 \\
\text { others including } \\
\text { teachers. An } \\
\text { interpretative } \\
\text { analysis was } \\
\text { conducted, } \\
\text { with interview } \\
\text { data coded } \\
\text { independently by } \\
\text { researchers, and } \\
\text { emergent themes } \\
\text { identified before } \\
\text { a meeting to } \\
\text { negotiate a shared } \\
\text { understanding of } \\
\text { the data. }\end{array}$ & $\begin{array}{l}\text { Participants } \\
\text { were seven } \\
\text { senior secondary } \\
\text { school (17- } \\
19 \text { years of } \\
\text { age) students } \\
\text { with visual } \\
\text { impairment, } \\
\text { attending } \\
\text { five different } \\
\text { mainstream } \\
\text { schools. } \\
\text { Four students } \\
\text { were legally } \\
\text { blind, and } \\
\text { two had low } \\
\text { vision. For brief } \\
\text { interviews: } \\
\text { Three Heads } \\
\text { of Education } \\
\text { Supports, two } \\
\text { parents, three } \\
\text { aides, and } \\
\text { eight teachers } \\
\text { participated. }\end{array}$ & $\begin{array}{l}\text { The following three } \\
\text { themes emerged: } \\
\text { time issue, access } \\
\text { to schoolwork issue } \\
\text { and challenges } \\
\text { pertaining to } \\
\text { the teacher, and } \\
\text { aides' support } \\
\text { and training. Poor } \\
\text { communication } \\
\text { was observed } \\
\text { among teachers, } \\
\text { aides, students, } \\
\text { and parents, and } \\
\text { understanding of } \\
\text { educational equity } \\
\text { was insufficient in } \\
\text { schools. Although } \\
\text { adjustments for } \\
\text { students to enable } \\
\text { equitable, quality, } \\
\text { and inclusive } \\
\text { education was } \\
\text { legally mandated, } \\
\text { it was not } \\
\text { evident from the } \\
\text { experiences of } \\
\text { the students in the } \\
\text { study. }\end{array}$ \\
\hline $\begin{array}{l}\text { Opie \& } \\
\text { Southcott } \\
\text { (2015) } \\
\text { 【Barriers } \\
\text { in inclusive } \\
\text { education】 } \\
\text { 【Successful } \\
\text { components } \\
\text { of inclusive } \\
\text { education】 }\end{array}$ & Australia & $\begin{array}{l}\text { To explore the } \\
\text { educational } \\
\text { experience of a } \\
\text { year } 12 \text { student } \\
\text { with visual } \\
\text { impairment } \\
\text { studying in } \\
\text { mainstream } \\
\text { school. }\end{array}$ & $\begin{array}{l}\text { Qualitative } \\
\text { method. } \\
\text { Single case } \\
\text { phenomenological } \\
\text { study, using } \\
\text { an indepth, } \\
\text { semi-structured } \\
\text { interview. An } \\
\text { Interpretative } \\
\text { Phenomenological } \\
\text { Analysis (IPA) was } \\
\text { conducted. }\end{array}$ & $\begin{array}{l}\text { Participant was } \\
\text { one male student } \\
\text { with visual } \\
\text { impairment in } \\
\text { year 12. Student } \\
\text { attended a } \\
\text { private school } \\
\text { without an } \\
\text { education } \\
\text { support unit. } \\
\text { Student was } \\
\text { supported } \\
\text { by qualified } \\
\text { education } \\
\text { support teachers, } \\
\text { and school } \\
\text { psychologist, } \\
\text { and was eligible } \\
\text { for visiting } \\
\text { specialist } \\
\text { teachers twice a } \\
\text { term. }\end{array}$ & $\begin{array}{l}\text { Major factor, } \\
\text { which impacted the } \\
\text { student's school life, } \\
\text { was social issues. } \\
\text { Participating in } \\
\text { blind sports outside } \\
\text { school facilitated } \\
\text { close connections } \\
\text { with peers and was } \\
\text { uplifting. }\end{array}$ \\
\hline
\end{tabular}




\begin{tabular}{|c|c|c|c|c|c|}
\hline Author \& Date & Country & Research Purpose & Methods & Participants & Findings \\
\hline $\begin{array}{l}\text { Thurston } \\
\text { (2014) } \\
\text { 【Barriers } \\
\text { in inclusive } \\
\text { education】 } \\
\text { 【Feelings of } \\
\text { acceptance in } \\
\text { an inclusive } \\
\text { environment】 }\end{array}$ & $\begin{array}{l}\text { United } \\
\text { Kingdom }\end{array}$ & $\begin{array}{l}\text { To examine } \\
\text { perceptions of } \\
\text { two VI students } \\
\text { with albinism } \\
\text { in the United } \\
\text { Kingdom on } \\
\text { inclusion and } \\
\text { using low-vision } \\
\text { aids in school }\end{array}$ & $\begin{array}{l}\text { Qualitative } \\
\text { research. Interview } \\
\text { using open } \\
\text { questions was } \\
\text { conducted. } \\
\text { An interpretative } \\
\text { phenomenological } \\
\text { analysis (IPA) was } \\
\text { conducted. }\end{array}$ & $\begin{array}{l}\text { Participants } \\
\text { included two } \\
\text { high school } \\
\text { students with } \\
\text { albinism. One } \\
\text { female (age } \\
16 \text { ) and one } \\
\text { male (age } 15) ; \\
10 \% \text { functional } \\
\text { vision, stable } \\
\text { since birth. }\end{array}$ & $\begin{array}{l}\text { Experiencing low } \\
\text { vision in school had } \\
\text { physical, social, } \\
\text { and emotional } \\
\text { consequences. } \\
\text { Both VI students } \\
\text { perceived low } \\
\text { vision aids as } \\
\text { beneficial, allowing } \\
\text { them to see better; } \\
\text { however, there were } \\
\text { drawbacks such as } \\
\text { complexity of using, } \\
\text { transporting, lack } \\
\text { of functionality, and } \\
\text { not being able to } \\
\text { "blend in". }\end{array}$ \\
\hline $\begin{array}{l}\text { West et. al } \\
\text { (2004) } \\
\text { 【Barriers } \\
\text { in inclusive } \\
\text { education】 } \\
\\
\text { 【Successful } \\
\text { components } \\
\text { of inclusive } \\
\text { education】 }\end{array}$ & Singapore & $\begin{array}{l}\text { To examine the } \\
\text { perspectives of } \\
\text { VI students on } \\
\text { their inclusion } \\
\text { in Singapore } \\
\text { mainstream } \\
\text { (secondary) } \\
\text { schools. }\end{array}$ & $\begin{array}{l}\text { Qualitative } \\
\text { method was used. } \\
\text { Semi-structured } \\
\text { interviews with } \\
\text { students; diary } \\
\text { entries and casual } \\
\text { observations were } \\
\text { documented. Two- } \\
\text { step coding was } \\
\text { used for analysis. } \\
\text { Specific techniques } \\
\text { for generating } \\
\text { meaning from } \\
\text { the data and } \\
\text { confirming } \\
\text { findings were } \\
\text { adopted. } \\
\text { Triangulation was } \\
\text { also implemented. }\end{array}$ & $\begin{array}{l}\text { Participants } \\
\text { were nine } \\
\text { VI students } \\
\text { ( } 3 \text { males, } 6 \\
\text { females) from } \\
\text { ages 13-17 } \\
\text { years. Seven had } \\
\text { low vision; one } \\
\text { used Braille, } \\
\text { one used both } \\
\text { Braille and } \\
\text { low vision } \\
\text { technology. } \\
\text { All students } \\
\text { attended } \\
\text { government } \\
\text { mainstream } \\
\text { secondary } \\
\text { schools. Eight } \\
\text { were in a normal } \\
\text { academic } \\
\text { stream; one was } \\
\text { in the express } \\
\text { stream. All } \\
\text { students were } \\
\text { educated in } \\
\text { special schools } \\
\text { during their } \\
\text { primary school } \\
\text { age years. }\end{array}$ & $\begin{array}{l}\text { Four propositions on } \\
\text { perspectives of VI } \\
\text { students emerged; } \\
\text { need of VI students' } \\
\text { feelings and abilities } \\
\text { acknowledged by } \\
\text { significant others; } \\
\text { must make major } \\
\text { adjustments to } \\
\text { their new learning } \\
\text { environment; benefit } \\
\text { of receiving support } \\
\text { and assistance from } \\
\text { peers; and benefit } \\
\text { from the assistance } \\
\text { of teachers who } \\
\text { acted as a "bridge" } \\
\text { in their social } \\
\text { relationships with } \\
\text { peers. }\end{array}$ \\
\hline
\end{tabular}




\begin{tabular}{|c|c|c|c|c|c|}
\hline Author \& Date & Country & Research Purpose & Methods & Participants & Findings \\
\hline $\begin{array}{l}\text { Whitburn } \\
\text { (2014) } \\
\text { 【Successful } \\
\text { components } \\
\text { of inclusive } \\
\text { education】 }\end{array}$ & Australia & $\begin{array}{l}\text { To examine the } \\
\text { experiences of } \\
\text { young people } \\
\text { with VI with } \\
\text { inclusive } \\
\text { schooling }\end{array}$ & $\begin{array}{l}\text { Qualitative } \\
\text { exploratory } \\
\text { framework was } \\
\text { used; grounded } \\
\text { theory design. } \\
\text { Semi-structured } \\
\text { focus group and } \\
\text { individual face- } \\
\text { to-face interviews } \\
\text { were conducted. }\end{array}$ & $\begin{array}{l}\text { Participants } \\
\text { included five } \\
\text { legally blind } \\
\text { students, four } \\
\text { boys and one } \\
\text { girl, aged 13-17 } \\
\text { years, learning } \\
\text { in an inclusive } \\
\text { secondary } \\
\text { school with } \\
\text { a specialist } \\
\text { teacher of } \\
\text { students with } \\
\text { VI. }\end{array}$ & $\begin{array}{l}\text { Two elements } \\
\text { emerged as central to } \\
\text { effective inclusion: } \\
\text { (1) having seamless } \\
\text { access to the } \\
\text { academic and social } \\
\text { dimensions of the } \\
\text { school, and (2) being } \\
\text { able to perform } \\
\text { autonomously and } \\
\text { independently. } \\
\text { Facilitators for } \\
\text { inclusion include } \\
\text { having physical } \\
\text { access to school, } \\
\text { being able to select } \\
\text { academic subjects } \\
\text { freely, and being able } \\
\text { to attend the same } \\
\text { class with peers. } \\
\text { Class teacher's } \\
\text { understanding and } \\
\text { use of resources, } \\
\text { effective pedagogy, } \\
\text { and friendship were } \\
\text { also important. } \\
\text { Overall, students } \\
\text { were under } \\
\text { pressure to prove } \\
\text { their capabilities } \\
\text { to both staff and } \\
\text { peers by excelling } \\
\text { academically and } \\
\text { performing well } \\
\text { socially. }\end{array}$ \\
\hline
\end{tabular}

\section{Barriers in Inclusive Education}

Within the 16 articles that we reviewed, 11 articles delineated barriers in inclusive education (Brydges \& Mkandawire, 2017; De Verdier \& Ek, 2014; George \& Duquette, 2006; Jessup et al., 2017; Jessup et al., 2018; Lieberman et al., 2006; Opie, 2018; Opie et al., 2017; Opie \& Southcott, 2015; Thurston, 2014; West et al., 2004). The three major barrier components were categorized as physical or environmental barriers, barriers in accessing the curriculum or instruction, and social barriers.

\section{Physical Barriers}

Physical barriers refer to the larger space, class size, and the higher noise level of schools, especially in the lower secondary school and high school (Opie, 2018;
Opie et al., 2017; Thurston, 2014). West et al. (2004) investigated the perceptions of nine students with visual impairment learning in a mainstream secondary school. These students had previously attended a special school and had to adjust to the different physical environment. Although physical barriers can be mitigated by students with adequate orientation and mobility training, it was not rare to find that students had to overrely on paraprofessionals or peers because they lacked the necessary skill or the confidence (Brydges \& Mkandawire, 2017; West et al., 2004).

\section{Barriers in Accessing Curriculum or Instruction}

Barriers pertaining to accessing the curriculum or instruction were most commonly discussed in our review. These barriers were experienced by students in 
high school more than in primary school (De Verdier \& Ek, 2014; West et al., 2004) and were prevalent more in subjects such as mathematics, science, and physical education (Brydges \& Mkandawire, 2017; George \& Duquette, 2006; Jessup et al., 2017; Lieberman et al., 2006). This situation was documented by research studies in countries such as the United States, Australia, Canada, Singapore, and Africa, indicating that this may be a universally faced issue.

One of the major factors, which contributed to inaccessibility of the curriculum or instruction, was the lack of adaptation, modification, or differentiation of teaching strategies. For instance, De Verdier and Ek (2014) examined the academic achievement of six students with visual impairment in inclusive settings. These researchers reported that students with visual impairment unintentionally performed tasks that were completely different from their sighted classmates because neither the material nor the activity in class was properly adapted. Inaccessible didactics used by teachers, such as rapid chalk and talk (rapidly talking or writing on the board without reading it out loud) and the use of visual aids such as movies without adequate auditory explanations, were also reported as challenges. In addition, the handwritten feedbacks and notes of the teachers were impossible for the students to decipher (Whitburn, 2014).

Although a few researchers indicated that some teachers did provide accommodations, which facilitated accessibility, the reality seems to be that such accommodations depended on the individual teacher. De Verdier and Ek (2014) revealed that the level of modifications varied to an extent that some students with visual impairment in high school had to choose courses/curriculum not based on their interest, but on the teacher's ability and willingness to make the curriculum accessible. Thus, the difficulty in accessibility increased in high school not just because of higher academic demands, but also because of the actions of general education teachers involved with students with visual impairment. Overall, obtaining a satisfactory level of support from school and classroom teachers seemed to be an endless struggle in a number of countries (De Verdier \& Ek, 2014; Opie et al., 2017).

In addition to the lack of modifications by teachers, students with visual impairment experienced barriers associated with a time issue. Several articles indicated that students in inclusive setting were constantly pressed for time (Opie, 2018; Opie et al., 2017; Thurston, 2014). West et al. (2004) reported that students with visual impairment were often in a situation where they had to choose between academic endeavors or social interactions. That is, the more time students spent studying, the less time they had available for socializing with peers. Some students were left with no option but to leave the accelerated academic stream and enroll in the slower paced academic stream to maintain a balance (West et al., 2004).

In essence, the above time issue reflected several complex factors related to barriers. Because of a high academic demand and the fast pace of instruction, all students, including those without disabilities, had little or no free time. This is a universal challenge that all students in high school encountered. For students with visual impairment, time was even more limited. Students who engage in reading using braille via the tactile mode or large print via low vision (or by using low vision devises) required more time to complete tasks.

Whitburn (2014) documented a case where a teacher's handwritten note regarding a room change caused a lost of time for students with visual impairment. That is, students lost valuable instructional time in the classroom because they needed assistance to decipher the written message and, consequently, to orientate to the new locations. In another situation, appropriate materials for students with visual impairment were not ready at the beginning of the class, and students had to attend to the lesson without the materials.

Another barrier example involved the utilization of appropriate technology. Opie et al. (2017) referred to a case where technology, which can be a tool for empowerment, worked against students with 
visual impairment. For instance, some technological equipment by students with visual impairment was too large to carry or required too much time to assemble, causing them to lose invaluable instructional time. It is detrimental for students if they are not able to utilize technology during their time in class.

One alarming approach, undertaken by a number of students, was to take digital pictures of the information on the chalkboard. Then, after arriving home, the students recorded (wrote down) the message, which they could not access in the classroom. Rewriting the notes from images meant redoing the entire lesson again, and as Opie (2018) remarked "when where were five to six classes a day, this was just not possible" (p. 657). The above situation can be alleviated if teachers of students with visual impairment obtain sufficient technical training.

\section{Social Barriers}

The last barrier identified was the social barrier. According to Opie and Southcott (2015), this barrier impacted the student's academic achievement and sense of well-being. As is the case for all children, social interaction with peers was critical for students with visual impairment. However, because of the visual impairment, many students faced difficulties. For example, these students had difficulty with locating people at a distance and with navigation; this limited peer interactions. Whitburn (2014) quoted one of the students he interviewed: "It [was] hard to engage with friends when you can't find them" ( $p$. 11). In addition, the challenges of being able to read facial expressions and possessing uneven social skills made social interactions even more complicated.

Building friendship takes time, but for some students, grasping opportunities to build relationships was simply difficult. Opportunities for students with visual impairment to interact with peers in an inclusive setting seem to occur spontaneously and in a split second. Opie and Southcott (2015) conducted a single case phenomenological study, which explored the educational experience of a 12-year old male student with visual impairment. The researchers described a situation, which depicts the harsh reality of the sighted world:

"if someone comes into the quadrangle at a school and says, "how are you?" I naturally just say "I'm good, how are you?" not having a clue who it was and a second later I may realize but it's too late; it is that split second that separates me from anybody else." (p. 73)

Interestingly, several researchers documented the effectiveness of a buddy system in facilitated friendships, particularly for students with low vision (Opie \& Southcott, 2015; West et al., 2004; Whitburn, 2014). In this system, a classroom teacher assigns a peer or peers to support the student with visual impairment. Whitburn (2014) revealed that low vision students had more friends compared to blind students because low-vision children are paired up with peers in class whereas students with blindness typically received support from teaching assistants or paraprofessionals. Thus, blind students had fewer opportunities to make friends than low-vision students.

Our review of the literature revealed that age and the level of vision influenced the social interactions of students with visual impairment. As students got older, friendships became more difficult to establish; the more severe the vision, the more challenges for students. Male students experienced difficulty in displaying their athletic ability, which was important in joining a circle of friends. Females also struggled socially. Peer exclusion and rejection were experienced by a number of male and female students with visual impairment (Brydges \& Mkandawire, 2017; Jessup et al., 2018; Opie \& Southcott, 2015). To assist with building social skills, Jessup et al. (2018) suggested the need for developing strategies to cope with exclusion and rejection. 
Feelings of Acceptance in an Inclusive Environment

Five studies focused on the feelings of students with visual impairment in the inclusive environment (Brydges \& Mkandawire, 2017; Jessup et al., 2017; Jessup et al., 2018; Koutsouris, 2014; Thurston, 2014). In general, the review of literature indicated that students with visual impairment felt accepted and that learning in an inclusive setting was beneficial (Brydges \& Mkandawire, 2017; Jessup et al., 2017; Jessup et al., 2018). For instance, by using Experience Sampling Methodology as one of their measures, Jessup et al. (2017) examined the experiences of 12 students with visual impairments. They found that students felt accepted and had enjoyable experiences more than half of the time spent in school. The researchers indicated that students with visual impairment felt they fit in when they were engaged in activities, fully aware of the surroundings, and had the support of staff or peers. On the other hand, students felt isolated, least accepted, and most lonely when they were not fully aware of surroundings and situations. Students experienced negative feelings when they were not involved in sports (sitting on the sidelines) or when teachers were using inaccessible instructional methods in class (Jessup et al., 2017).Although students with visual impairment felt accepted, many had the awareness of being different from their peers due to their visual disability. Thurston (2014) examined the perceptions of low-vision students with albinism in an inclusive setting. These students indicated that their feeling of "different" stemmed from their conspicuous looks such as light colored hair, nystagmus, and actions to compensate for their disability (such as sitting in the front of the class; using technology). Similarly, Jessup et al. (2018) and Whitburn (2014) stated that students felt different because they had to do things differently, compared to their sighted peers (e.g., use technology or ask for support, etc.).

This feeling of difference seems to be selfdriven (i.e., an internal perception). Students with visual impairment were not being treated differently by peers. However, Thurston (2014) and Whitburn (2014) stated that this feeling of being different led some students to yearn for friendships with sighted peers just to feel normal or to achieve normalcy. Thurston described this as the "negative cyclical process of inclusion" (p. 116).

Koutsouris (2014) emphasized the complexity of inclusion in relation to students' emotions. This researcher documented a tension between homophily, which is a preference for social interactions with similar others, and inclusion, which can be characterized by the presence of diverse individuals, who are sighted peers. Koutsouris interviewed 27 students, including nine students with visual impairment. The research showed that it was natural for students both with and without disabilities to have a preference for homophily. Students opined that this was an individual choice, which should be respected. However, students also understood the importance of inclusion (and it was more a moral obligation); thus, this created tension. Homophily and inclusion were equally desirable ethical values that needed to be balanced. One of the suggestions was the need for a gradual approach, allowing students to be engaged in multiple dialogues.

\section{Successful Components of Inclusive Education}

Nine articles focused on successful components of inclusive education (Bishop, 1986; Chang \& Schaller, 2002; George \& Duquette, 2006; Hess, 2010; Jessup et al., 2018; Lieberman et al., 2006; Opie \& Southcott, 2015; West et al., 2004; Whitburn, 2014). We categorized major themes as positive school climate and teacher attitude, teachers with knowledge and skills, and autonomy and assertiveness.

\section{Positive School Climate and Teacher Attitude}

Support for inclusive education requires a positive school climate and teachers' acceptance of the concept of inclusion as well as of students with visual impairment. In a quantitative study, Hess (2010) 
analyzed the interrelationships of the school climate, teachers' attitude, and the quality of life (QOL) of students with visual impairment. The researcher reported that when the school climate and teachers' attitude towards inclusion were positive, there was a positive significant correlation between the teachers' assessment of the students (social, emotional, and learning domains) and the students' evaluation of their quality of life (i.e., attitude, coping strategies, emotional state).

In a single case design, George and Duquette (2006) reported similar findings. They stressed the eminent roles of teachers and the school. In this study, the schoolteachers embraced an inclusive education philosophy. In essence, they saw beyond the student's disability to capitalize on the student's learning strength, similar to what they did with all other students. All students, including those with visual impairments, were an integral part of the learning community.

The positiveness seen in the overall school climate and teacher's attitude seems to be the bedrock of inclusion. This is the case not only because modifications in instructional strategies are needed, but also, without a positive climate, these modifications for students with visual impairment can trigger negative attitudes from other students. This may result in the social isolation of students with visual impairment (Brydges \& Mkandawire, 2017; Whitburn, 2014). Furthermore, within a negative atmosphere, students with visual impairment may desire to be seen as normal and refuse support, including the use of technology, to supplement their vision (Jessup et al., 2018; Whitburn, 2014).

\section{Teachers with Knowledge and Skills}

There is little debate that support from a highly qualified teacher of the visually impaired (TVI) is essential for a successful inclusion environment (e.g., Bishop, 1986). In addition, it is critical for general education teachers to possess knowledge and practical skills to support students' academic and emotional needs because a TVI is usually only available for a limited amount of time in inclusive settings. Students with visual impairment should be learning the same content as peers without disabilities. These students require accommodations (e.g., providing materials in accessible formats; technology), and general education teachers should have high expectations, equivalent to those for sighted students. Bishop (1986) argued that promotion on the basis of effort or sympathy might create an unnatural success for students with visual impairment and will not be beneficial later in the world of employment. Several studies documented unproductive learning environments, constructed by unsympathetic teachers and paraprofessionals, who misjudged the capabilities of students with visual impairment (Opie et al. 2017; West et al., 2004; Whitburn, 2014).

General education teachers need specific skills such as flexibility (Bishop, 1986; Lieberman et al., 2006), variety in instructional strategies (Chang \& Schaller, 2002; Lieberman et al., 2006), and good communication (Opie et al., 2017). Effective instructional strategies include the use of tactile cues, verbal information, active learning, and cooperative learning groups (Chang \& Schaller, 2002; Lieberman et al., 2006). Teachers who utilized a combination of different strategies tend to enable students with visual impairment to participate in class on a par with peers (Whitburn, 2014). Good communication with paraprofessionals, TVIs, parents, and students with visual impairment is also necessary (Opie et al., 2017). It is essential for general education teachers to reach out to TVIs and paraprofessionals so that accessible resources are available to students in a timely fashion. Similarly, reaching out to students with visual impairment and also being approachable in and outside class are equally important.

Via semi-structured in-depthinterviews, Chang and Schaller (2002) investigated the perceptions of 12 students with visual impairment regarding teachers' support of their needs. The researchers concluded that the emotional connection or closeness with teachers was important for students to develop awareness 
of their emotions and strengthen their capacity for coping with stressful situations. There were two broad traits found in teachers, appreciated by the students: The teacher's ability to listen to their emotional needs and to offer encouragement (Chang \& Schaller, 2002; see also, George \& Duquette, 2006). Students also appreciate teachers who believed that they were as intellectually capable as sighted students and pushed them academically. West et al. (2004) indicated that student's perceptions towards teachers change positively only when they believed that teachers are able to look beyond their visually impairment.

Lastly, teachers, who act as a facilitator or a bridge between students with visual impairment and sighted peers, also received a strong appreciation by students. According to West et al. (2004), students with visual impairment found it difficult to ask peers for assistance, even for relatively simple tasks. However, if teachers act as a bridge by initiating buddy partnerships with class peers, students with visual impairment felt much more comfortable to ask for assistance. Similar findings were echoed by the research of Whitburn (2014).

\section{Autonomy and Assertiveness}

From our review of the selected articles, the third major component associated with a successful inclusion placement entailed two constructs, autonomy and assertiveness. Students with visual impairment need to possess the ability to work autonomously (or independently) and to be assertive in expressing their needs and in social interactions with others (Jessup et al., 2018; Whitburn, 2014). As reported by Whitburn (2014), students with visual impairment considered inclusive education to be effective if they could make individual choices and were able to complete tasks with minimal intervention from teachers and staff.

Possessing autonomy allows students with visual impairment to feel empowered. Students need to develop adequate skills such as reading and writing, the use of Braille, and orientation and mobility
(Bishop, 1986). Students also needed the skills to utilize a variety of technology. The adequate and ease of use of technology enabled students to take control over their schoolwork by making it accessible without having to depend predominantly on the assistance of others (Jessup et al., 2018).

With respect to assertiveness, Jessup et al. (2018) used a mixed methodology to investigate the inclusion of 12 students in Australian high schools. It was documented that students with visual impairment who felt socially included were those who were assertive in initiating and engaging in productive social interactions. Building relationships with sighted peers required considerable effort for students with visual impairment although assistance from teachers and paraprofessionals certainly helped. In general, students with visual impairment who were not autonomous or assertive felt socially excluded (Jessup et al., 2018).

Developing social interaction skills is part of the Expanded Core Curriculum. In addition, students with visual impairment need to be able to demonstrate their skills and talents in an inclusive setting - that is, they need situations where they can shine. Jessup et al. (2018) remarked that many students with visual impairment who were successfully included had a place where they shined, or in other words, engaged in activities they felt skilled at performing and were acknowledged by others. For some students, this was during recess when they were with good friends. For others, it was out of school, where they played adapted sports hosted by a local disability sports group or special schools.

Jessup et al. (2018) emphasized that these activities did not need to be academically related. Rather, it was imperative for students with visual impairment to beengaged in meaningful and productive activities, which led to the cultivation of their selfesteem. These findings were also documented by the work of Opie and Southcott (2015). In their case study, the researchers identified an activity that seem to contribute to a successful inclusive placementswish. This is a version of table tennis developed for 
individuals with visual impairment in Australia by an organization for individuals with visual impairment. Similar sport activities, which can promote inclusion and collaboration, include goal ball (playing soccer with a noise-induced ball) and other activities in which sound plays an integral part of the game for individuals with visual impairment.

\section{CONCLUSION}

This was a seminal study that provided an integrative analysis of the perceptions of students with visual impairment on inclusive education. We began with an overview of research on inclusion and students with visual impairment and then focused on the perceptions of these students. We categorized the perceptions into three broad areas: barriers, feelings of acceptance, and successful components of inclusion. Admittedly, there were overlaps among these areas, and some studies covered more than one category.

Most of the reviewed articles discussed barriers, which pertained to the physical environment of schools, accessibility, and social interactions or intercourses. Barriers in accessing the curriculum or instruction were the most discussed topic, and specific subjects such as mathematics, science, and physical education were highlighted as most challenging to include students with visual impairment. Students with visual impairment also had challenges with initiating and building friendships with sighted peers.

Insights into the second category, feelings of acceptance, highlighted the social challenges of students with visual impairment. In order to fit in, students needed to be fully aware of their surroundings and be supported by teachers, staff, and peers. Students did not want to stand out or feel different albeit some students did support the construct of homophily - that is, the desire to associate with others who are similar in character or attitude.

A number of students did feel that inclusion was beneficial, especially if there was a positive school climate. It was also helpful if general education teachers exhibited a positive attitude and were accepting of the students, treating them with respectand acknowledging their ability to do well academically and socially with some assistance. General education teachers do need to acquire a better understanding of teaching strategies, including adaptation, modification, and differentiation of materials. It is also critical to understand the importance of instructional presentation of information, orientation and mobility, and the use of technology.

Not surprisingly, students with visual impairment were most successful in an inclusive environment if they possessed autonomy and assertiveness. To feel empowered, students needed skills such as reading, writing, and the use of Braille and technology. With these skills (and others such as self-determination and advocacy), students can work independently with some assistance from teachers and staff. In addition, students may develop a level of self-confidence that can propel them to initiate and build friendships with sighted peers.

Admittedly, the present research is not the first study to emphasize the importance of factors pertaining to school, teachers, and students with visual impairment. For example, Bishop (1986) conducted a survey and reported several factors conducive to successful inclusion. The flexibility of teachers was ranked at the top, followed by student factors such as possessing good social and academic skills and a positive self-image. Similar findings were echoed by Simui et al. (2018), who conducted a literature review on the inclusion of students with visual impairment in higher education.

Nevertheless, the present study is unique in that we focused predominantly on the perceptions of students with visual impairment. We documented the qualities of teachers appreciated by students such as possessing basic knowledge of visual impairment, looking beyond students' disability and believing in their capabilities to perform and be successful as their sighted peers. As mentioned previously, students with visual impairment also acknowledged the need to possess skills that permitted them to be autonomous and assertive. These skills not only facilitated 
academic success, but also contributed to feelings of acceptance and fitting in socially with their sighted peers.

Limitations of the present study should be acknowledged. Although this study only included articles that were published in peer-reviewed journals and eliminated articles that had inadequately described methods or results, a rigorous assessment of quality indicators was not conducted (e.g., validity, reliability, etc.). It is recommended that future investigations focus on the evaluation of quality indicators. It is possible that our development of categories and integration of the findings are open to varying interpretations. Our interpretations should be evaluated by other independent scholars. Although, we feel that we conducted a fairly exhaustive review of the literature, it is possible that we have unintentionally neglected to include a few relevant investigations that met our inclusion criteria. In essence, the conclusions of the present study should be viewed with some caution. Nevertheless, it is asserted that the findings advance our understanding of the perceptions of students with visual impairment with respect to developing an effective or successful inclusive education program.

\section{REFERENCES}

NOTE: Articles that are asterisked (*) have been reviewed in the present study.

*Bishop, V. E. (1986). Identifying the components of success in mainstreaming. Journal of Visual Impairment \& Blindness, 80, 939-946.

Booth, A., Sutton, A., \& Papioannou, D. (2016). Systematic approaches to a successful literature review ( $2^{\text {nd }}$ ed.). London, England: SAGE.

Braun, V., \& Clarke, V. (2006). Using thematic analysis in psychology. Qualitative Research in Psychology, 3(2), 77-101. https://doi.org/10.1191/1478088706qp063oa

*Brydges, C., \& Mkandawire, P. (2017). Perceptions and concerns about inclusive education among students with visual impairments in Lagos, Nigeria. International Journal of Disability, Development and Education, 64(2), 211-225. https://doi.org/10.1080/1034912X.2016.1183768

Byrnes, M. A. (2017). Taking sides: Clashing views on controversial issues in special education (6th ed.). Dubuque, IA: McGraw-Hill/Dushkin.
*Chang, S.C. \& Schaller, J. (2002). The views of students with visual impairments on the support they received from teachers. Journal of Visual Impairment \& Blindness, 558575.

Collins, J. A., \& Fauser, B. C. J. M. (2005). Balancing the strengths of systematic and narrative reviews. Human Reproduction Update, 11(2), 103-104. https://doi. org/10.1093/humupd/dmh058

Council for Exceptional Children. (2014). Council for Exceptional Children standards for evidence-based practices in special education. Exceptional Children, 80, 504-511. doi:10.1177/0014402914531388.

*De Verdier, K., \& Ek, U. (2014). A longitudinal study of reading development, academic achievement, and support in Swedish inclusive education for students with blindness or severe visual impairment. Journal of Visual Impairment and Blindness, 108(6), 461-472. https://doi.org/10.4028/ www.scientific.net/AMM.204-208.659

Gall, M.D., Gall, J.P., \& Borg, W. R. (2007). Educational research: An introduction ( $8^{\text {th }}$ ed.). Boston, MA: Allyn \& Bacon.

Gall, M.D., Gall, J.P., \& Borg, W. R. (2015). Applying educational research: How to read, do, and use research to solve problems of practice ( $7^{\text {th }}$ ed.). Boston, MA: Pearson/ Allyn \& Bacon.

Galvan, J. L. (2012). Writing literature reviews: A guide for students of the social and behavioral sciences ( $\left.5^{\text {th }} \mathrm{ed}.\right)$. Glendale, CA: Pyrczak

*George, A. L., \& Duquette, C. (2006). The psychosocial experiences of a student with low vision. Journal of Visual Impairment and Blindness, 100(3), 152-163.

Haegele, J. A., \& Porretta, D. (2015). Physical activity and school-age individuals with visual impairments: A literature review. Adapted Physical Activity Quarterly, 32(1), 68-82. https://doi.org/10.1123/apaq.2013-0110

Haegele, J. A., \& Zhu, X. (2017). Experiences of individuals with visual impairments in integrated physical education: A retrospective study. Research Quarterly for Exercise and Sport, 88(4), 425-435. https://doi.org/10.1080/02701 367.2017 .1346781

*Hess, I. (2010). Visually impaired pupils in mainstream schools in Israel: Quality of life and other associated factors. The British Journal of Visual Impairment, 28(1), 19-33. https:// doi.org/10.1177/0264619609347242

*Jessup, G., Bundy, A. C., Broom, A., \& Hancock, N. (2017). The social experiences of high school students with visual impairments. Journal of Visual Impairment \& Blindness, 111(1), 5-19.

*Jessup, G. M., Bundy, A. C., Hancock, N., \& Broom, A. (2018). Being noticed for the way you are: Social inclusion and high school students with vision impairment. British 
Journal of Visual Impairment, 36(1), 90-103. https://doi. org/10.1177/0264619616686396

Kalloniatis, M., \& Johnston, A. W. (1994). Visual environmental adaptation problems of partially sighted children. Journal of Visual Impairment and Blindness, 88(3), 234-243.

*Koutsouris, G. (2014). Young people's preferences for social interaction in terms of homophily and social inclusion: A critical discussion about respect. European Journal of Special Needs Education, 29(4), 521-535. https://doi.org/1 $0.1080 / 08856257.2014 .933547$

*Lieberman, L. J., Robinson, B. L., \& Rollheiser, H. (2006). Youth with visual impairments: Experiences in general physical education. RE:View: Rehabilitation and Education for Blindness and Visual Impairment, 38(1), 35-48. https://doi.org/10.3200/revu.38.1.35-48

Morris, M., \& Smith, P. (2007). Educational provision for blind and partially sighted children and young people in Britain: 2007. Royal National Institute of Blind People, London.

*Opie, J. (2018). Technology today: Inclusive or exclusionary for students with vision impairment? International Journal of Disability Development and Education, 65(6), 649-663.

*Opie, J., Deppeler, J., \& Southcott, J. (2017). 'You have to be like everyone else': Support for students with vision impairment in mainstream secondary schools. Support for Learning, 32(3), 267-287. https://doi.org/10.1111/14679604.12169

*Opie, J., \& Southcott, J. (2015). Schooling through the eyes of a student with vision impairment. International Journal on School Disaffection, 11(2), 67-77.

Simui, F., Kasonde-Ngandu, S., Cheyeka, A.M. Simwinga, \& J., Ndhlove, D. (2018). Enablers and disablers to academic success of students with visual impairment: A 10-year literature disclosure, 2007-2017. British Journal of Visual Impairment, 36(2), 163-174.

Thomas, G., \& Vaughan, M. (2004). Inclusive education: Readings and reflections. New York, NY: McGraw-Hill Education

*Thurston, M. (2014). “They think they know what's best for me": An interpretative phenomenological analysis of the experience of inclusion and support in high school for vision-impaired students with albinism. International Journal of Disability, Development and Education, 61(2), 108-118.

U.S. Department of Education, National Center for Education Statistics (2017). Digest of Education Statistics, 2016. U.S. Department of Education, National Center for Education Statistics. Retrieved from: https:/nces.ed.gov/fastfacts/ display.asp?id=59

Valle, J. W., \& Conner, D J. (2011). Rethinking disability: A disability studies approach to inclusive practices. New York, NY: McGraw-Hill.
*West, J. Houghton, S. Taylor, \& J. Ling, P.K. (2004). The perspectives of Singapore secondary schools with vision impairments towards their inclusion in mainstream education. Australasian Journal of Special Education, 28(1), 18-27.

*Whitburn, B. (2014). Accessibility and autonomy preconditions to "our" inclusion: A grounded theory study of the experiences of secondary students with vision impairment. Journal of Research in Special Educational Needs, 14(1), 3-15. https://doi.org/10.1111/1471-3802.12014

Winzer, M. A. (2009). From integration to inclusion: A history of special education in the 20th century. Washington, DC: Gallaudet University Press

Yero, J. L. (2002). Teaching in mind: How teacher thinking shapes education. Hamilton, MT: MindFlight Publishing. 